\title{
The Synergistic Effect of Plasminogen Activator Inhibitor-1 (PAI-1) Polymorphisms and Metabolic Syndrome on Coronary Artery Disease in the Korean Population
}

\author{
Han Sung Park ${ }^{1,+}$, Jung-Hoon Sung ${ }^{2,+} \mathbb{D}$, Chang Soo Ryu ${ }^{1}$, Jeong Yong Lee ${ }^{1}$, Eun Ju Ko ${ }^{1}$, \\ In Jai Kim ${ }^{2, *}$ and Nam Keun Kim ${ }^{1, *(\mathbb{D})}$ \\ 1 Department of Biomedical Science, College of Life Science, CHA University, Seongnam 13488, Korea; \\ hahnsung@naver.com (H.S.P.); regis2040@nate.com (C.S.R.); smilee3625@naver.com (J.Y.L.); \\ ejko05@naver.com (E.J.K.) \\ 2 Department of Cardiology, CHA Bundang Medical Center, CHA University, Seongnam 13496, Korea; \\ atropin5@cha.ac.kr \\ * Correspondence: mdij24@chol.com (I.J.K.); nkkim@cha.ac.kr (N.K.K.) \\ + These authors contributed equally to this work.
}

Received: 28 October 2020; Accepted: 25 November 2020; Published: 28 November 2020

\begin{abstract}
The most common type of cardiovascular disease is coronary artery disease (CAD), in which a plaque builds up inside the coronary arteries that can lead to a complete blockage of blood flow to the heart, resulting in a heart attack. The CAD may be affected by various factors including age, gender, and lipoprotein disposition as well as genetic factors and metabolic syndrome. In this study, we investigated whether three PAI-1 polymorphisms ( $-844 \mathrm{G}>\mathrm{A},-6754 \mathrm{G}>5 \mathrm{G}$, and $+43 \mathrm{G}>\mathrm{A}$ ) and CAD-related clinical parameters are associated with CAD susceptibility. Genotyping of $463 \mathrm{CAD}$ patients and 401 controls was performed using polymerase chain reaction restriction fragment length polymorphism analysis. We report that the 4G5G genotype (crude odds ratio(COR), 1.392; $95 \%$ confidence interval $(\mathrm{CI}), 1.036-1.871 ; p=0.028)$ and dominant model (4G4G vs. 4G5G + 5G5G; COR, $1.401 ; 95 \%$ CI, 1.060-1.850; $p=0.018$; adjust odds ratio, $1.371 ; 95 \%$ CI, $1.027-1.831 ; p=0.032$ ) of PAI-1 -675 polymorphisms were associated with increased CAD risk. Haplotype and genotype combinations of PAI- $1-675$ and +43 polymorphisms show an increased risk of CAD according to alterations of the -675 polymorphism allele or genotype. Moreover, the PAI-1 -675 polymorphisms show a synergistic effect with the metabolic syndrome component of CAD risk. This study suggests that polymorphisms in the PAI-1 genes along with the metabolic syndrome component of CAD can be useful biomarkers for CAD diagnosis and treatment.
\end{abstract}

Keywords: coronary artery disease; PAI-1 polymorphism; metabolic syndrome

\section{Introduction}

Coronary artery disease (CAD), a cardiovascular disease, is one of the main causes of death in developing countries [1]. CAD is still the leading cause of mortality in Europe, the United States, and Asia [2]. CAD is primarily caused by a buildup of plaque in the coronary artery wall that supplies blood to the heart. Therefore, CAD can weaken the heart muscle and may lead to a serious condition called heart failure that decreases the ability of the heart to pump blood efficiently [3]. This atherosclerotic disease is highly affected by inflammation, higher low-density lipoprotein (LDL) cholesterol, lower high-density lipoprotein (HDL) cholesterol, and plaque formation [4]. However, atherosclerotic disease can also develop at lower LDL-cholesterol levels when risk factors such as 
age, gender, hypertension, diabetes mellitus, and genetic susceptibility are present [5]. Moreover, the heritability of CAD is estimated at 40 to $50 \%$ using an updated genome-wide approach [5], and various studies report that numerous polymorphisms of fibrin clotting and fibrinolysis-related genes are associated with CAD susceptibility [6,7].

Following the formation of a fibrin clot, the fibrinolytic system is initiated by the conversion of plasminogen to plasmin [8]. Plasmin is activated by serine proteases such as tissue plasminogen activator (tPA) and urokinase plasminogen activators (uPA) and contributes to vascular smooth muscle migration and neointimalization through degradation of fibronectin and laminin $[9,10]$. Moreover, plasmin is involved in the degradation of fibrin and the activation of matrix metalloproteases (MMP), which induce the degradation of elastin and collagen in the extracellular matrix [11]. This fibrinolytic system may be inhibited by regulation of the plasminogen activator inhibitor-1 (PAI-1).

The PAI-1 gene, officially named SERPINE1, encodes a member of the serine proteinase inhibitor super family. The PAI-1 gene is located on chromosome 7 (7q22.1) and PAI-1 is mainly produced by the endothelium. This proteolytic factor is a principal regulatory protein in the fibrinolytic system, and has roles as a main inhibitor of tPA and uPA [12]. An abnormal increase in expression or activity of PAI-1 has been reported to be associated with impaired fibrinolysis [13]. Moreover, several polymorphisms in the PAI-1 gene may be involved in the alteration of PAI-1 expression and are associated with various diseases.

The +43 G > A polymorphism (rs6092, Ala15Thr) in the first exon of the PAI-1 gene is associated with plasma insulin levels [14], type 2 diabetes and related metabolic traits [15], and osteonecrosis [16]. The $-844 \mathrm{~A}>\mathrm{G}$ polymorphism (rs2227631) is located in the promotor region of the PAI-1 gene, leads to increased PAI-1 protein levels, and is associated with osteonecrosis of the femoral head, osteoporotic vertebral compression fracture [17], and acute coronary syndrome [18,19]. The $-6754 \mathrm{G}>5 \mathrm{G}$ polymorphism (rs1799762), located in the PAI-1 promotor region, is also reported to be associated with various atherosclerotic diseases including venous thromboembolism [20], ischemic stroke [21], carotid artery stenosis [22], renal artery stenosis [23], and coronary artery disease [24]. Moreover, these three polymorphisms are reported to be associated with plasma PAI-1 levels $[25,26]$. Therefore, we designed a genetic epidemiological study of the three most extensively studied polymorphisms of PAI-1 to investigate the association between PAI-1 and CAD in Korean populations.

\section{Results}

\subsection{Clinical Characteristics of the Study Participants}

Baseline characteristics of the CAD patients and controls are presented in Table 1. The age and gender of CAD patients and controls were statistically matched. The mean age of CAD patients (mean \pm standard deviation (SD), $60.40 \pm 11.68$ ) and control participants (mean \pm SD, $60.02 \pm 11.46$ ) were not significantly different. Moreover, the male ratio of CAD patients and controls was not significantly different (202/463 (43.6\%) and 171/401 (42.6\%), respectively). The mean body mass index (BMI) of CAD patients (mean \pm SD, $25.09 \pm 3.59$ ) was significantly higher than controls (mean $\pm S D$, $24.19 \pm 3.31)$. Hypertension was significantly higher in CAD patients than controls $(248(53.6 \%)$ and $149 / 401(37.2 \%), p<0.0001)$. Additionally, the ratios of diabetes mellitus $(p<0.0001)$ and metabolic syndrome (MetS) $(p<0.0001)$ in CAD patients and controls were significantly different. The clinical parameters of total cholesterol $(p=0.004)$ and creatinine $(p=0.0004)$ were significantly different between CAD patients and controls. However, triglyceride $(p=0.061)$, HDL-cholesterol $(p=0.086)$, LDL-cholesterol $(p=0.184)$, homocysteine $(p=0.142)$, vitamin B12 $(p=0.833)$, and folate $(p=0.264)$ were not significantly different between the two groups. 
Table 1. Baseline characteristics between CAD and controls.

\begin{tabular}{|c|c|c|c|}
\hline Characteristic & $\begin{array}{l}\text { Controls } \\
(n=401)\end{array}$ & $\begin{array}{l}\text { CAD Patients } \\
\quad(n=463)\end{array}$ & $p$ \\
\hline Age (years, mean \pm SD) & $60.02 \pm 11.46$ & $60.40 \pm 11.68$ & 0.703 \\
\hline Male $(\%)$ & $171(42.6)$ & $202(43.6)$ & 0.771 \\
\hline $\mathrm{BMI}\left(\mathrm{kg} / \mathrm{m}^{2}\right.$, mean $\left.\pm \mathrm{SD}\right)$ & $24.19 \pm 3.31$ & $25.09 \pm 3.59$ & 0.001 \\
\hline Hypertension $(\mathrm{n}, \%)$ & $149(37.2)$ & $248(53.6)$ & $<0.0001$ \\
\hline Diabetes mellitus (n, \%) & $48(12.0)$ & $118(25.5)$ & $<0.0001$ \\
\hline Hyperlipidemia (n, \%) & $88(21.9)$ & $119(25.7)$ & 0.174 \\
\hline Smoking $(\mathrm{n}, \%)$ & $141(35.2)$ & $148(32.0)$ & 0.403 \\
\hline Metabolic syndrome (n, \%) & $62(15.5)$ & $209(45.1)$ & $<0.0001$ \\
\hline Total cholesterol $(\mathrm{mg} / \mathrm{dL}$, mean $\pm \mathrm{SD})$ & $191.76 \pm 37.43$ & $185.65 \pm 45.97$ & 0.004 \\
\hline Triglyceride $(\mathrm{mg} / \mathrm{dL}$, mean $\pm \mathrm{SD})$ & $143.25 \pm 88.91$ & $155.03 \pm 92.46$ & 0.061 \\
\hline HDL-cholesterol $(\mathrm{mg} / \mathrm{dL}$, mean $\pm \mathrm{SD})$ & $46.01 \pm 14.00$ & $43.71 \pm 11.35$ & 0.086 \\
\hline LDL-cholesterol $(\mathrm{mg} / \mathrm{dL}$, mean $\pm \mathrm{SD})$ & $116.16 \pm 40.84$ & $111.42 \pm 39.17$ & 0.184 \\
\hline Homocysteine $(\mu \mathrm{mol} / \mathrm{L}$, mean $\pm \mathrm{SD})$ & $9.79 \pm 4.18$ & $9.65 \pm 4.85$ & 0.142 \\
\hline Vitamin B12 $(\mathrm{pg} / \mathrm{mL}$, mean $\pm \mathrm{SD})$ & $675.99 \pm 259.21$ & $710.04 \pm 346.17$ & 0.833 \\
\hline Folate $(\mathrm{nmol} / \mathrm{L}$, mean $\pm \mathrm{SD})$ & $8.88 \pm 7.99$ & $8.27 \pm 7.58$ & 0.264 \\
\hline Creatinine $(\mathrm{mg} / \mathrm{dL}$, mean $\pm \mathrm{SD})$ & $0.94 \pm 0.23$ & $1.48 \pm 6.65$ & 0.0004 \\
\hline
\end{tabular}

Note: CAD, coronary artery disease; BMI, body mass index; HDL, high-density lipoprotein; LDL, low-density lipoprotein.

\subsection{Genotype Frequencies Comparison Analysis}

To evaluate the association of the three polymorphisms (PAI-1 -844 G > A, PAI-1 -675 4G > 5G, and PAI-1 +43 G > A) with CAD susceptibility, the genotype frequencies between CAD patients and control participants were compared and summarized in Table 2. The frequency of the PAI-1 $-6754 \mathrm{G}>5 \mathrm{G}$ polymorphism was significantly different in the 4G5G genotype and dominant model (4G4G vs. 4G5G + 5G5G). The crude odds ratio (COR) and $p$-value of the dominant model were 1.401 and 0.018 , respectively. Moreover, the significance of the dominant model was maintained in adjusted statistical analysis (adjusted odds ratio (AOR), 1.371; $p=0.032$ ) using age, gender, hypertension, diabetes mellitus, hyperlipidemia, and smoking status.

Genotype analysis of the MetS subgroup was performed to investigate whether the associations of the three polymorphisms change according to the existence or nonexistence of MetS (results summarized in Table 3). The CAD patients and controls were divided into four subgroups according to MetS, and the genotype frequencies of controls with non-MetS were compared. The CAD patients in the MetS groups in the dominant model of PAI-1 $-6754 \mathrm{G}>5 \mathrm{G}$ polymorphism (AOR, 1.519; $p=0.045$ ) are associated with increased CAD susceptibility. 
Table 2. Genotype frequencies of PAI-1 polymorphisms in CAD and controls.

\begin{tabular}{|c|c|c|c|c|c|c|c|c|}
\hline Genotypes & $\begin{array}{l}\text { Controls } \\
(n=401)\end{array}$ & $\begin{array}{c}\text { CAD } \\
(n=463)\end{array}$ & COR $(95 \% \mathrm{CI})$ & $p$ & FDR- $p$ & AOR $(95 \% \mathrm{CI})$ & $p$ & FDR- $p$ \\
\hline \multicolumn{9}{|l|}{ PAI-1 -844 G > A } \\
\hline GG & 135 (33.7) & $167(36.1)$ & & & & & & \\
\hline GA & $196(48.9)$ & $214(46.2)$ & $0.883(0.655-1.189)$ & 0.412 & 0.525 & $0.820(0.601-1.119)$ & 0.211 & 0.352 \\
\hline AA & $70(17.5)$ & $82(17.7)$ & $0.947(0.640-1.401)$ & 0.785 & 0.785 & $0.960(0.633-1.455)$ & 0.847 & 0.847 \\
\hline Dominant (GG vs. GA + AA) & & & $0.900(0.679-1.191)$ & 0.460 & 0.690 & $0.853(0.637-1.143)$ & 0.287 & 0.478 \\
\hline Recessive (GG + GA vs. AA) & & & $1.018(0.716-1.446)$ & 0.922 & 0.922 & $1.085(0.755-1.558)$ & 0.661 & 0.826 \\
\hline HWE- $P$ & 0.937 & 0.351 & & & & & & \\
\hline \multicolumn{9}{|l|}{ PAI-1-675 4G > 5G } \\
\hline $4 \mathrm{G} 4 \mathrm{G}$ & $162(40.4)$ & $151(32.6)$ & & & & & & \\
\hline $4 \mathrm{G} 5 \mathrm{G}$ & $178(44.4)$ & $231(49.9)$ & $1.392(1.036-1.871)$ & 0.028 & 0.084 & $1.342(0.987-1.824)$ & 0.060 & 0.151 \\
\hline $5 \mathrm{G} 5 \mathrm{G}$ & $61(15.2)$ & $81(17.5)$ & $1.425(0.956-2.124)$ & 0.083 & 0.124 & $1.503(0.992-2.276)$ & 0.054 & 0.272 \\
\hline Dominant (4G4G vs. 4G5G + 5G5G) & & & $1.401(1.060-1.850)$ & 0.018 & 0.054 & $1.371(1.027-1.831)$ & 0.032 & 0.127 \\
\hline Recessive (4G4G + 4G5G vs. 5G5G) & & & $1.182(0.822-1.699)$ & 0.367 & 0.5505 & $1.259(0.866-1.830)$ & 0.227 & 0.568 \\
\hline HWE- $P$ & 0.297 & 0.649 & & & & & & \\
\hline \multicolumn{9}{|l|}{$P A I-1+43 \mathrm{G}>\mathrm{A}$} \\
\hline GG & $333(83.0)$ & $382(82.5)$ & & & & & & \\
\hline GA & $62(15.5)$ & $80(17.3)$ & $1.125(0.783-1.617)$ & 0.525 & 0.525 & $1.229(0.843-1.791)$ & 0.283 & 0.354 \\
\hline GG & $6(1.5)$ & $1(0.2)$ & $0.145(0.017-1.213)$ & 0.075 & 0.125 & $0.191(0.022-1.633)$ & 0.131 & 0.326 \\
\hline Dominant (GG vs. GA + GG) & & & $1.038(0.729-1.480)$ & 0.835 & 0.835 & $1.145(0.792-1.654)$ & 0.472 & 0.589 \\
\hline Recessive (GG + GA vs. GG) & & & $0.143(0.017-1.189)$ & 0.072 & 0.216 & $0.185(0.022-1.589)$ & 0.124 & 0.568 \\
\hline HWE- $P$ & 0.123 & 0.13 & & & & & & \\
\hline
\end{tabular}

diabetes mellitus, hyperlipidemia, and smoking status. 
Table 3. Genotype frequencies of PAI-1 polymorphisms according to metabolic syndrome (MetS).

\begin{tabular}{|c|c|c|c|c|c|c|c|c|c|c|}
\hline Genotypes & $\begin{array}{l}\text { Non-MetS } \\
\text { Controls } \\
(n=296)\end{array}$ & $\begin{array}{c}\text { MetS } \\
\text { Control } \\
(n=105)\end{array}$ & $\begin{array}{c}\text { AOR } \\
(95 \% \mathrm{CI})\end{array}$ & $p$ & $\begin{array}{c}\text { Non-MetS } \\
\text { CAD } \\
(n=189)\end{array}$ & $\begin{array}{c}\text { AOR } \\
(95 \% \mathrm{CI})\end{array}$ & $p$ & $\begin{array}{c}\text { MetS CAD } \\
(n=274)\end{array}$ & $\begin{array}{c}\text { AOR } \\
(95 \% \mathrm{CI})\end{array}$ & $p$ \\
\hline \multicolumn{11}{|l|}{$P A I-1-844 \mathrm{G}>\mathrm{A}$} \\
\hline GG & $103(34.8)$ & $32(30.5)$ & $\begin{array}{c}1.000 \\
\text { (reference) }\end{array}$ & & $68(36.0)$ & $\begin{array}{c}1.000 \\
\text { (reference) }\end{array}$ & & $99(36.1)$ & $\begin{array}{c}1.000 \\
\text { (reference) }\end{array}$ & \\
\hline GA & $137(46.3)$ & $59(56.2)$ & $\begin{array}{c}1.003 \\
(0.553-1.820)\end{array}$ & 0.991 & $86(45.5)$ & $\begin{array}{c}0.907 \\
(0.590-1.395)\end{array}$ & 0.658 & $128(46.7)$ & $\begin{array}{c}0.872 \\
(0.562-1.351)\end{array}$ & 0.539 \\
\hline AA & $56(18.9)$ & $14(13.3)$ & $\begin{array}{c}0.786 \\
(0.366-1.687)\end{array}$ & 0.537 & $35(18.5)$ & $\begin{array}{c}0.923 \\
(0.533-1.596)\end{array}$ & 0.773 & $47(17.2)$ & $\begin{array}{c}0.800 \\
(0.448-1.429)\end{array}$ & 0.451 \\
\hline Dominant (GG vs. GA + AA) & & & $\begin{array}{c}0.939 \\
(0.541-1.630)\end{array}$ & 0.824 & & $\begin{array}{c}0.914 \\
(0.613-1.362)\end{array}$ & 0.658 & & $\begin{array}{c}0.854 \\
(0.569-1.281)\end{array}$ & 0.445 \\
\hline Recessive (GG + GA vs. AA) & & & $\begin{array}{c}0.750 \\
(0.372-1.515)\end{array}$ & 0.423 & & $\begin{array}{c}1.024 \\
(0.631-1.661)\end{array}$ & 0.925 & & $\begin{array}{c}0.848 \\
(0.510-1.413)\end{array}$ & 0.528 \\
\hline \multicolumn{11}{|l|}{ PAI-1 $-6754 \mathrm{G}>5 \mathrm{G}$} \\
\hline $4 \mathrm{G} 4 \mathrm{G}$ & $124(41.9)$ & $38(36.2)$ & $\begin{array}{c}1.000 \\
\text { (reference) }\end{array}$ & & $68(36.0)$ & $\begin{array}{c}1.000 \\
\text { (reference) }\end{array}$ & & $83(30.3)$ & $\begin{array}{c}1.000 \\
\text { (reference) }\end{array}$ & \\
\hline $4 \mathrm{G} 5 \mathrm{G}$ & $130(43.9)$ & $48(45.7)$ & $\begin{array}{c}1.103 \\
(0.626-1.945)\end{array}$ & 0.735 & $87(46.0)$ & $\begin{array}{c}1.121 \\
(0.735-1.712)\end{array}$ & 0.596 & $144(52.6)$ & $\begin{array}{c}1.487 \\
(0.967-2.288)\end{array}$ & 0.071 \\
\hline $5 \mathrm{G} 5 \mathrm{G}$ & $42(14.2)$ & $19(18.1)$ & $\begin{array}{c}1.739 \\
(0.815-3.710)\end{array}$ & 0.152 & $34(18.0)$ & $\begin{array}{c}1.588 \\
(0.906-2.785)\end{array}$ & 0.107 & $47(17.2)$ & $\begin{array}{c}1.694 \\
(0.937-3.063)\end{array}$ & 0.081 \\
\hline Dominant (4G4G vs. 4G5G + 5G5G) & & & $\begin{array}{c}1.233 \\
(0.730-2.083)\end{array}$ & 0.434 & & $\begin{array}{c}1.233 \\
(0.832-1.827)\end{array}$ & 0.296 & & $\begin{array}{c}1.519 \\
(1.010-2.285)\end{array}$ & 0.045 \\
\hline Recessive (4G4G + 4G5G vs. 5G5G) & & & $\begin{array}{c}1.617 \\
(0.822-3.181)\end{array}$ & 0.164 & & $\begin{array}{c}1.495 \\
(0.899-2.484)\end{array}$ & 0.121 & & $\begin{array}{c}1.347 \\
(0.794-2.283)\end{array}$ & 0.269 \\
\hline \multicolumn{11}{|l|}{ PAI- $1+43 \mathrm{G}>\mathrm{A}$} \\
\hline GG & $241(81.4)$ & $92(87.6)$ & $\begin{array}{c}1.000 \\
\text { (reference) }\end{array}$ & & $157(83.1)$ & $\begin{array}{c}1.000 \\
\text { (reference) }\end{array}$ & & $225(82.1)$ & $\begin{array}{c}1.000 \\
\text { (reference) }\end{array}$ & \\
\hline GA & $51(17.2)$ & $11(10.5)$ & $\begin{array}{c}0.552 \\
(0.252-1.211)\end{array}$ & 0.138 & $31(16.4)$ & $\begin{array}{c}0.930 \\
(0.560-1.545)\end{array}$ & 0.780 & $49(17.9)$ & $\begin{array}{c}1.181 \\
(0.711-1.962)\end{array}$ & 0.521 \\
\hline GG & $4(1.4)$ & $2(1.9)$ & $\begin{array}{c}2.008 \\
(0.262-5.406)\end{array}$ & 0.503 & $1(0.5)$ & $\begin{array}{c}0.502 \\
(0.055-4.590)\end{array}$ & 0.542 & $0(0.0)$ & N/A & 0.998 \\
\hline Dominant (GG vs. GA + GG) & & & $\begin{array}{c}0.629 \\
(0.301-1.314)\end{array}$ & 0.217 & & $\begin{array}{c}0.906 \\
(0.551-1.489)\end{array}$ & 0.696 & & $\begin{array}{c}1.106 \\
(0.670-1.824)\end{array}$ & 0.695 \\
\hline Recessive (GG + GA vs. GG) & & & $\begin{array}{c}2.083 \\
(0.280-5.476)\end{array}$ & 0.473 & & $\begin{array}{c}0.541 \\
(0.059-4.931)\end{array}$ & 0.586 & & N/A & 0.998 \\
\hline
\end{tabular}

Note: MetS, metabolic syndrome; AOR, adjusted odds ratio; CI, confidence interval; CAD, coronary artery disease. AOR: Adjusted by age, gender, hypertension, diabetes mellitus, hyperlipidemia, and smoking status. 


\subsection{Haplotype and Genotype Combination Analysis}

Haplotype and genotype combination analysis was performed to confirm the combined effect of the three SNPs. The results of haplotype and genotype combination analysis were summarized in Tables 4 and 5, respectively. In haplotype analysis of the PAI-1 -844 G > A/PAI-1 -675 4G > 5G/PAI-1 +43 G > A polymorphisms, G-4G-A (OR, 0.118; $p<0.0001)$, A-4G-A (OR, 0.019; $p<0.0001)$, G-5G-A $(\mathrm{OR}, 1.989 ; p=0.005)$, and A-5G-A (OR, 4.728; $p=0.002)$ are associated with CAD susceptibility. In haplotypes of two SNPs, A-5G (OR, 6.503; $p<0.0001)$ of PAI-1 -844 G > A/PAI-1 -675 4G > 5G, 4G-A (OR, $0.059 ; p<0.0001)$ and 5G-A (OR, 2.276; $p=0.0002)$ of PAI-1 -675/PAI-1 +43, and A-A (OR, $0.118 ; p=0.0001)$ of $P A I-1-844 / P A I-1+43$ are associated with CAD risk.

Table 4. Haplotype of the PAI-1 polymorphisms in coronary artery disease.

\begin{tabular}{|c|c|c|c|c|c|}
\hline Haplotype & $\begin{array}{c}\text { Controls } \\
(2 n=802)\end{array}$ & $\begin{array}{c}\text { CAD } \\
(2 n=926)\end{array}$ & $\begin{array}{c}\text { OR } \\
(95 \% \mathrm{CI})\end{array}$ & $p$ & $F D R-p$ \\
\hline \multicolumn{6}{|c|}{ PAI-1 -844 G > A/PAI-1 -675 4G > 5G/PAI-1 +43 G > A } \\
\hline G-4G-G & $148(18.5)$ & $180(19.4)$ & 1.000 (reference) & & \\
\hline G-4G-A & $21(2.7)$ & $3(0.3)$ & $0.118(0.034-0.402)$ & $<0.0001$ & 0.0004 \\
\hline G-5G-G & $265(33.0)$ & $291(31.4)$ & $0.903(0.687-1.187)$ & 0.486 & 0.567 \\
\hline G-5G-A & $31(3.9)$ & $75(8.1)$ & $1.989(1.241-3.188)$ & 0.005 & 0.009 \\
\hline A-4G-G & $311(38.8)$ & $350(37.9)$ & $0.925(0.709-1.207)$ & 0.588 & 0.588 \\
\hline A-4G-A & $21(2.7)$ & $0(0.0)$ & $0.019(0.001-0.319)$ & $<0.0001$ & 0.0004 \\
\hline A-5G-G & $4(0.5)$ & $23(2.5)$ & $4.728(1.599-13.980)$ & 0.002 & 0.005 \\
\hline A-5G-A & $0(0.0)$ & $4(0.5)$ & $7.404(0.395-138.700)$ & 0.132 & 0.185 \\
\hline \multicolumn{6}{|c|}{ PAI-1 $-844 \mathrm{G}>\mathrm{A} / P A I-1-675 \mathrm{G}>\mathrm{A} 4 \mathrm{G}>5 \mathrm{G}$} \\
\hline G-4G & $170(21.2)$ & $183(19.7)$ & 1.000 (reference) & & \\
\hline $\mathrm{G}-5 \mathrm{G}$ & $296(36.9)$ & $365(39.5)$ & $1.146(0.884-1.484)$ & 0.321 & 0.482 \\
\hline $\mathrm{A}-4 \mathrm{G}$ & $332(41.4)$ & $350(37.8)$ & $0.979(0.757-1.267)$ & 0.896 & 0.896 \\
\hline A-5G & $4(0.5)$ & $28(3.0)$ & $6.503(2.234-18.930)$ & $<0.0001$ & 0.0003 \\
\hline \multicolumn{6}{|c|}{ PAI-1 -844 G > A/PAI-1 +43 G > A } \\
\hline G-G & $413(51.6)$ & $472(50.9)$ & 1.000 (reference) & & \\
\hline G-A & $53(6.6)$ & $76(8.2)$ & $1.255(0.863-1.825)$ & 0.257 & 0.386 \\
\hline A-G & $315(39.2)$ & $372(40.2)$ & $1.033(0.846-1.262)$ & 0.760 & 0.760 \\
\hline A-A & $21(2.7)$ & $6(0.6)$ & $0.250(0.100-0.626)$ & 0.002 & 0.006 \\
\hline \multicolumn{6}{|c|}{ PAI-1 -675 4G > 5G/PAI-1 +43 G > A } \\
\hline $4 \mathrm{G}-\mathrm{G}$ & $458(57.1)$ & $530(57.2)$ & 1.000 (reference) & & \\
\hline $4 \mathrm{G}-\mathrm{A}$ & $44(5.5)$ & $3(0.3)$ & $0.059(0.018-0.191)$ & $<0.0001$ & 0.0003 \\
\hline $5 \mathrm{G}-\mathrm{G}$ & $270(33.6)$ & $314(33.9)$ & $1.005(0.819-1.234)$ & 0.962 & 0.962 \\
\hline $5 \mathrm{G}-\mathrm{A}$ & $30(3.8)$ & $79(8.5)$ & $2.276(1.468-3.529)$ & 0.0002 & 0.0003 \\
\hline
\end{tabular}

Note: $\mathrm{CAD}$, coronary artery disease; $\mathrm{OR}$, odds ratio; $\mathrm{CI}$, confidence interval; FDR, false discovery rate.

Table 5. Genotype combinations of the PAI-1 polymorphisms in coronary artery disease.

\begin{tabular}{ccccc}
\hline Combination & $\begin{array}{c}\text { Controls } \\
(\boldsymbol{n}=\mathbf{4 0 1})\end{array}$ & $\begin{array}{c}\text { CAD Patients } \\
(\boldsymbol{n}=\mathbf{4 6 3 )}\end{array}$ & $\begin{array}{c}\text { AOR } \\
(\mathbf{9 5 \%} \text { CI) }\end{array}$ & $p$ \\
\hline PAI-1 -844 G $>$ A/PAI-1 -675 4G $>5 G$ & & & & \\
GG/4G4G & $24(6.0)$ & $23(5.0)$ & 1.000 (reference) & 0.241 \\
GG/4G5G & $52(13.0)$ & $71(15.3)$ & $1.566(0.740-3.312)$ & 0.339 \\
GG/5G5G & $59(14.7)$ & $73(15.8)$ & $1.429(0.687-2.974)$ & 0.739 \\
GA/4G4G & $69(17.2)$ & $60(13.0)$ & $0.886(0.434-1.808)$ & 0.549 \\
GA/4G5G & $125(31.2)$ & $147(31.7)$ & $1.223(0.633-2.362)$ & 0.234 \\
GA/5G5G & $2(0.5)$ & $7(1.5)$ & $3.052(0.486-19.172)$ & 0.793 \\
AA/4G4G & $69(17.2)$ & $68(14.7)$ & $1.102(0.533-2.279)$ & 0.022 \\
AA/4G5G & $1(0.2)$ & $13(2.8)$ & $13.157(1.463-118.330)$ & N/A \\
AA/5G5G & $0(0.0)$ & $1(0.2)$ & N/A &
\end{tabular}


Table 5. Cont.

\begin{tabular}{|c|c|c|c|c|}
\hline Combination & $\begin{array}{l}\text { Controls } \\
(n=401)\end{array}$ & $\begin{array}{l}\text { CAD Patients } \\
\quad(n=463)\end{array}$ & $\begin{array}{c}\text { AOR } \\
(95 \% \mathrm{CI})\end{array}$ & $p$ \\
\hline \multicolumn{5}{|c|}{ PAI-1 -844 G > A/PAI-1 +43 G > A } \\
\hline GG/GG & $106(26.4)$ & $120(25.9)$ & 1.000 (reference) & \\
\hline GG/GA & $25(6.2)$ & $46(9.9)$ & $2.215(1.213-4.042)$ & 0.010 \\
\hline GG/AA & $4(1.0)$ & $1(0.2)$ & $0.269(0.028-2.556)$ & 0.253 \\
\hline GA/GG & $167(41.6)$ & $183(39.5)$ & $0.942(0.665-1.335)$ & 0.737 \\
\hline GA/GA & $27(6.7)$ & $31(6.7)$ & $1.001(0.542-1.850)$ & 0.997 \\
\hline GA/AA & $2(0.5)$ & $0(0.0)$ & $\mathrm{N} / \mathrm{A}$ & N/A \\
\hline AA/GG & $60(15.0)$ & $79(17.1)$ & $1.291(0.819-2.036)$ & 0.271 \\
\hline AA/GA & $10(2.5)$ & $3(0.6)$ & $0.273(0.069-1.088)$ & 0.066 \\
\hline $\mathrm{AA} / \mathrm{AA}$ & $0(0.0)$ & $0(0.0)$ & N/A & N/A \\
\hline \multicolumn{5}{|c|}{ PAI-1 -675 4G > 5G/PAI-1 +43 G > A } \\
\hline $4 \mathrm{G} 4 \mathrm{G} / \mathrm{GG}$ & $131(32.7)$ & $149(32.2)$ & 1.000 (reference) & \\
\hline 4G4G/GA & $30(7.5)$ & $2(0.4)$ & $0.062(0.014-0.269)$ & 0.0001 \\
\hline 4G4G/AA & $1(0.2)$ & $0(0.0)$ & N/A & N/A \\
\hline 4G5G/GG & $156(38.9)$ & $185(40.0)$ & $1.003(0.722-1.394)$ & 0.985 \\
\hline 4G5G/GA & $19(4.7)$ & $46(9.9)$ & $2.089(1.142-3.824)$ & 0.017 \\
\hline 4G5G/AA & $3(0.7)$ & $0(0.0)$ & N/A & N/A \\
\hline 5G5G/GG & $46(11.5)$ & $48(10.4)$ & $0.867(0.531-1.416)$ & 0.568 \\
\hline 5G5G/GA & $13(3.2)$ & $32(6.9)$ & $2.558(1.252-5.224)$ & 0.010 \\
\hline 5G5G/AA & $2(0.5)$ & $1(0.2)$ & $0.630(0.054-7.330)$ & 0.712 \\
\hline
\end{tabular}

Note: CAD, coronary artery disease; AOR, adjusted odds ratio; CI, confidence interval. AOR: adjusted by age, gender, hypertension, diabetes mellitus, hyperlipidemia, and smoking status.

In genotype combination analysis, the 4G4G/GA (AOR, 0.062; $p=0.0001)$ of PAI-1 $-6754 \mathrm{G}>$ 5G/PAI-1 +43 G > A shows a decreased risk of CAD. In contrast, AA/4G5G (AOR, 13.157; $p=0.022)$ of PAI-1 -844 G > A/PAI-1 -675 4G > 5G, GG/GA (AOR, 2.215; $p=0.010)$ of PAI-1 -844 G > A/PAI-1 +43 $\mathrm{G}>\mathrm{A}, 4 \mathrm{G} 5 \mathrm{G} / \mathrm{GA}(\mathrm{AOR}, 2.089 ; p=0.017)$ and 5G5G/GA (AOR, 2.558; $p=0.010$ ) of PAI-1 $-6754 \mathrm{G}>$ 5G/PAI-1 +43 G > A genotype combinations are associated with a highly increased CAD risk.

Interestingly, when the $4 \mathrm{G}$ to $5 \mathrm{G}$ alteration of the PAI-1 -675 polymorphism is combined with the GA genotype or A allele of PAI-1 +34 polymorphism, there is an increased OR. When the GA genotype of the PAI-1 +43 G > A polymorphism is in combination with the PAI-1 -675 4G >5G/PAI-1 +43 G > A, the alterations of $P A I-1-675$ genotype leads to an increase in CAD risk. This pattern is maintained in the PAI-1 -675/PAI-1 +43 haplotype.

\subsection{Synergistic Effect of PAI-1 Polymorphisms with Clinical Parameter}

We investigated the synergistic effect of the PAI-1 polymorphisms with clinical parameters. Various clinical parameters showed synergistic effects with PAI-1 polymorphisms (Supplementary Table S1). The MetS-related clinical parameters combined with the PAI-1 -675 polymorphism are highly associated with an increased risk of CAD (Figure 1). The AORs of PAI-1 -675 4G5G + 5G5G group when combined with each parameters including hypertension, DM, hyperlipidemia, $\geq 25 \mathrm{~kg} / \mathrm{m}^{2}$ of BMI, $\geq 150 \mathrm{mg} / \mathrm{dL}$ of triglyceride levels, and $<40$ (male) $/<50$ (female) $\mathrm{mg} / \mathrm{dL}$ of HDL-cholesterol levels are $2.780(p<0.0001), 3.266(p<0.0001), 1.779(p=0.011), 4.050(p<0.0001), 1.714(p=0.011)$, and $6.781(p<0.0001)$. 


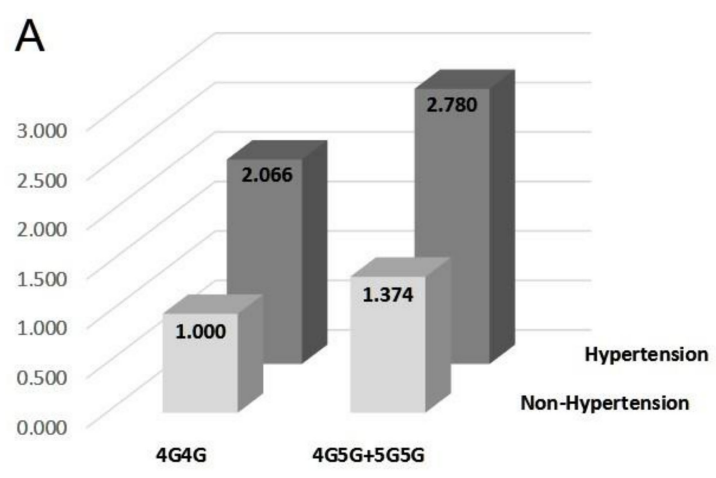

D

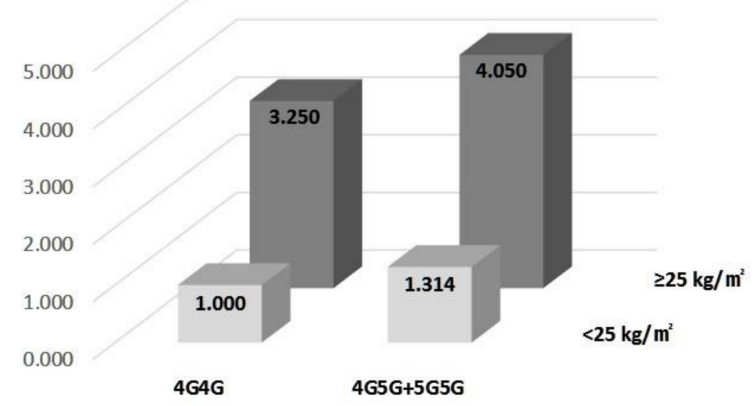

B

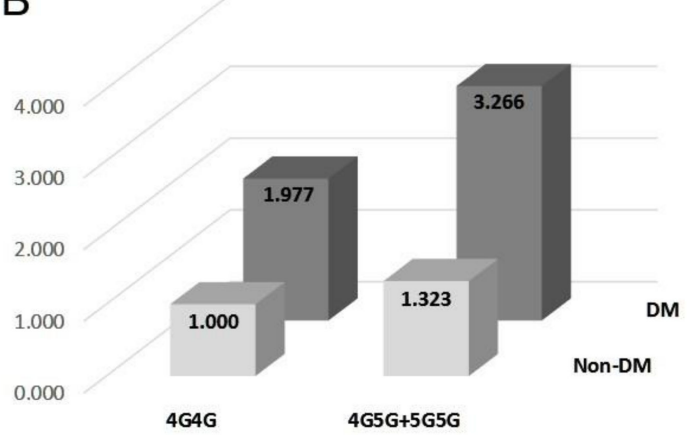

E

2.000
1.500
1.000
0.500
0.000

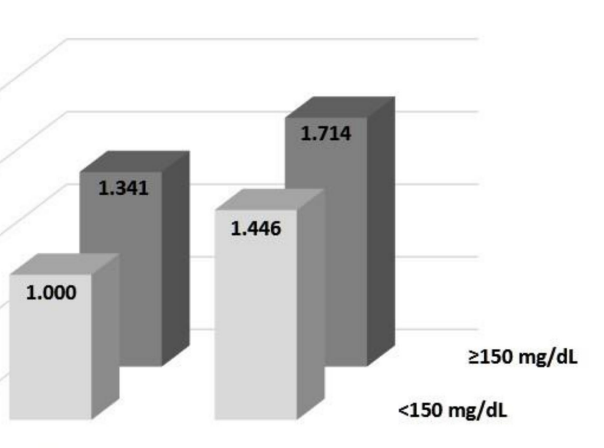

4G4G

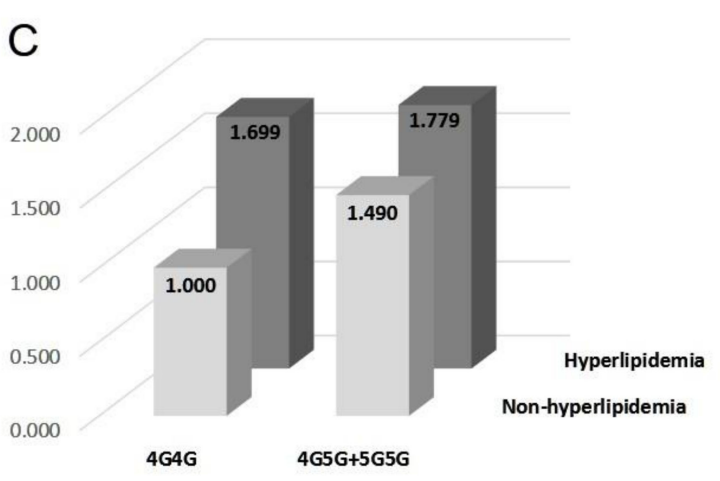

F

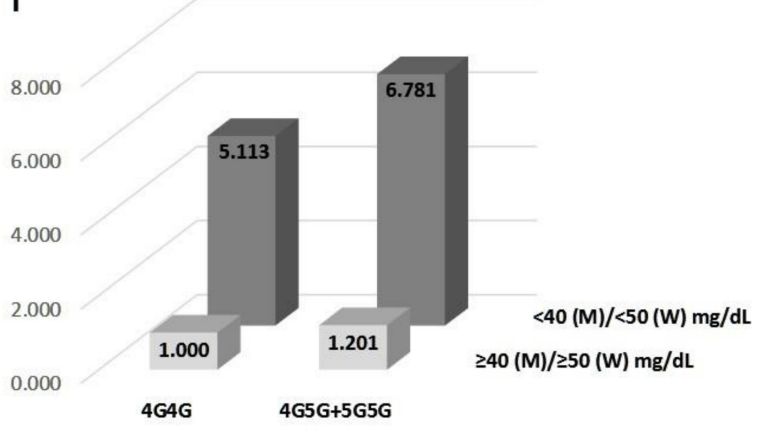

Figure 1. Synergistic effect of PAI-1 -675 4G > 5G polymorphism with metabolic syndrome-related clinical parameters. (A-F) panels show AOR of PAI-1 -675 4G > 5G with metabolic syndrome-related clinical parameters including hypertension (A), diabetes mellitus (B), hyperlipidemia (C), body mass index (D), triglyceride levels (E), and high-density lipoprotein cholesterol (F), respectively. 


\section{Discussion}

In this study, we investigated the association of three polymorphisms in the PAI-1 gene with differences in susceptibility of CAD. The polymorphism PAI-1 $+43 \mathrm{G}>\mathrm{A}$ is a missense variant in the first exon of the PAI-1 gene. The other two polymorphisms, PAI-1 -675 4G > 5G and PAI-1 -844 G > A, are in the promoter region of the PAI- 1 gene. Therefore, these three polymorphisms may act as functional polymorphisms that affect the regulation of gene expression and fibrinolysis.

In age and gender matched groups of CAD patients and controls, the genotype frequency comparison analysis shows that the 4G5G + 5G5G genotypes are associated with the CAD risk when compared with the 4G4G genotype in a dominant model of the PAI-1 -675 4G > 5G polymorphism. The association of the -675 polymorphism is more powerful when combined with the other PAI-1 polymorphisms. In the PAI-1 -675 4G > 5G/PAI-1 +43 G > A genotype combination analysis, the PAI-1 $-6754 \mathrm{G} 5 \mathrm{G} / \mathrm{PAI}-1+43 \mathrm{G}>\mathrm{A}$ combination shows that the susceptibility of CAD was gradually increased when the genotype of PAI-1 +43 G > A was GA and the genotypes of PAI-1 -675 4G > 5G changed from $4 \mathrm{G} 4 \mathrm{G}$ to $5 \mathrm{G} 5 \mathrm{G}$. These patterns of association are also shown in the two and three allele combination analyses. The CAD susceptibility is greatly increased when the allele of PAI-1 $+43 \mathrm{G}>\mathrm{A}$ is $\mathrm{A}$ and the allele of PAI-1 -675 4G > 5G is changed from $4 \mathrm{G}$ to $5 \mathrm{G}$ in the two allele combination analysis. In the three allele combination analysis, the CAD risk increases according to the alteration of $-6754 \mathrm{G}>5 \mathrm{G}$, when the $-844 \mathrm{G}>\mathrm{A}$ is the $\mathrm{G}$ allele and $+43 \mathrm{G}>\mathrm{A}$ is the A allele.

The serine proteinase inhibitor super family E member 1 is encoded by the PAI-1 gene. The PAI-1 is mainly produced by endothelial cells and stored at platelet. Secreted PAI-1 from alpha-granules of activated platelets and endothelial cells is incorporated into the coagulation process and plays a key role in thrombolysis resistance $[27,28]$. Moreover, the PAI-1 regulates the initiation of fibrinolytic processes through the inhibition of $\mathrm{PA}$ and $\mathrm{uPA}$. The PAI-1 polymorphisms were studied in various groups, populations, and diseases. The PAI-1 $-6754 \mathrm{G}>5 \mathrm{G}$ polymorphism is reported to be associated with increased susceptibility of atherosclerotic diseases in various populations. Numerous previous studies report that the PAI-1 -675 4G > 5G polymorphism overlaps with the enhancer box (E-box) which is recognized and bound by transcription factors to initiate gene transcription [29]. Moreover, the PAI-1 -675 4G > 5G polymorphism affects PAI-1 expression levels and various pathways including the thrombolytic and fibrinolytic pathway, and is associated with CAD [30]. Various meta-analysis of the PAI-1 -675 4G > 5G polymorphism show that the $5 \mathrm{G}$ allele is associated with increased CAD susceptibility [31-33].

Various studies have reported that the components of MetS and atherosclerotic diseases containing CAD are closely linked [34-37]. According to ATP III criteria, diagnosis of MetS is based on the presence of three or more of the five criteria including waist circumference (WC) $>102 \mathrm{~cm}$ in men and $>88 \mathrm{~cm}$ in women, high blood pressure (BP $\geq 130 / 85)$, high triglyceride (TG $\geq 150$ ), high fasting blood sugar (FBS $\geq 110)$, and low HDL-cholesterol ( $<40$ in men and $<50$ in women) [38]. Table 3 shows that the $4 \mathrm{G} 5 \mathrm{G}+5 \mathrm{G} 5 \mathrm{G}$ genotypes of the PAI-1 -675 variant in the MetS CAD group show increased AOR when compared to $4 \mathrm{G} 4 \mathrm{G}$ in non-MetS controls. Interestingly, the PAI-1 -675 variant and risk factors of MetS have a synergistic effect for increased susceptibility of CAD (Figure 1). Each group that has the PAI-1 -675 4G5G + 5G5G genotype and the six risk conditions for MetS including hypertension, DM, hyperlipidemia, BMI $\geq 25 \mathrm{~kg} / \mathrm{m} 2, \mathrm{TG} \geq 150 \mathrm{mg} / \mathrm{dL}$, and $\mathrm{HDL}<40 \mathrm{mg} / \mathrm{dL}$ (male) and $<50 \mathrm{mg} / \mathrm{dL}$ (female) exhibit a significantly increased $\mathrm{OR}(\mathrm{AOR}=2.780,3.266,1.779,4.050,1.714$ and 6.781 , respectively) when compared to the PAI-1-675 4G4G group with non-MetS conditions.

This study evaluates whether the three polymorphisms (PAI-1 -675 4G > 5G, PAI-1 -844 G > A, and PAI-1 $+43 \mathrm{G}>\mathrm{A}$ ) that may affect PAI-1 expression or activity are associated with susceptibility of CAD in the Korean population. The PAI-1 $-6754 \mathrm{G}>5 \mathrm{G}$ polymorphism is associated with CAD and the MetS-CAD subgroup. In combination analysis, some alleles and genotype combinations including the PAI-1 -675 4G > 5G polymorphism are associated with highly increased CAD susceptibility. Moreover, the PAI-1 -675 polymorphism and some conditions that may increase the risk of MetS show synergistic effects on CAD risk. This finding could be applied to identify new CAD prognostic biomarkers using 
the PAI-1 -675 polymorphism when combined with other PAI-1 polymorphisms and the component of MetS.

\section{Materials and Methods}

\subsection{Study Participants}

Blood samples were collected from 463 patients with CAD (age; mean \pm standard deviation (SD): $60.40 \pm 11.68$ years) and 401 healthy control participants (age; mean \pm SD: $60.02 \pm 11.46$ years). The participants were recruited from the Department of Cardiology of CHA Bundang Medical Center (Seongnam, South Korea) between 2014 and 2016. All participants gave written informed consent to this study, which was approved by the Institutional Review Board of CHA Bundang Medical Center (IRB number: 2013-10-114), and all study protocols followed the recommendations of the Declaration of Helsinki. In total, 463 patients with CAD were referred from the Department of Cardiology of CHA Bundang Medical Center, CHA University.

All patients had stenosis of more than $50 \%$ in at least one of the main coronary arteries or their major branches, which was confirmed by coronary angiography. To avoid issues in blood testing caused by various medical treatments, exclusion criteria included history of cardiac arrest and life expectancy $<1$ year. Diagnoses were made by coronary angiography and were confirmed by at least one independent experienced cardiologist.

We randomly selected 401 gender and age matched control participants from patients presented at the Department of Cardiology at the CHA Bundang Medical Center during the same period for comprehensive health check-up, including biochemical testing and cardiological examination. The control participants that had a history of angina symptoms or myocardial infarction and showed $\mathrm{T}$ wave inversion on electrocardiography were excluded in control subjects.

In this study, the criterion of hypertension was defined as systolic pressure $\geq 130 \mathrm{mmHg}$ and diastolic pressure $\geq 85 \mathrm{mmHg}$ and included patients currently taking hypertensive medications. Diabetes mellitus was defined as a fasting plasma glucose level $\geq 110 \mathrm{mg} / \mathrm{dL}$ and included patients taking diabetic medications. Hyperlipidemia was defined as a high fasting serum total cholesterol (TC) level ( $\geq 150 \mathrm{mg} / \mathrm{dL}$ ) or an anti-hyperlipidemic agent treatment history. Smoking status refers to patients who currently smoke.

\subsection{Blood Biochemical Analyses}

Blood was collected in anticoagulant tubes after $12 \mathrm{~h}$ of fasting. To separate plasma from whole blood, samples were centrifuged for $15 \mathrm{~min}$ at $1000 \times \mathrm{g}$. The plasma levels of homocysteine, folate, TC, TG, HDL-cholesterol, and LDL-cholesterol were determined [3].

\subsection{Genetic Analyses}

DNA was extracted from leukocytes in peripheral blood using G-dex II Genomic DNA Extraction kit (iNtRON Biotechnology, Inc., Seongnam, Korea), according to the manufacturer's instructions. Polymerase chain reaction (PCR) restriction fragment length polymorphism (RFLP) assays was performed to analyze the PAI-1 -884 G > A, PAI-1 -675 4G > 5G and PAI-1 +43 G > A polymorphisms [39]. To amplify the three polymorphic regions, three primer sets were used (Supplementary Table S2). The PCR conditions were based on the following steps: pre-denaturation was performed at $95^{\circ} \mathrm{C}$ for $10 \mathrm{~min}$, followed by 35 cycles with denaturation at $95^{\circ} \mathrm{C}$ for $30 \mathrm{~s}$, annealing at each optimized temperature for $30 \mathrm{~s}$, extension at $72{ }^{\circ} \mathrm{C}$ for $45 \mathrm{~s}$, and final extension was carried out at $72{ }^{\circ} \mathrm{C}$ for $7 \mathrm{~min}$. The PCR product was loaded in $3 \%$ agarose gel stained by nucleic acid staining solution and visualized using ultraviolet illuminator after $16 \mathrm{~h}$ of enzyme restriction. 


\subsection{Statistical Analysis}

In the clinical characteristics analysis of CAD patients and control participants, the student's $t$-test for continuous variables and the Chi-square test for categorical variables were used. To estimate the relative risk of the PAI-1 genotype for CAD occurrence, logistic regression analyses were performed using age, gender, hypertension, Diabetes mellitus, hyperlipidemia, and smoking status. For allele combination analysis, the Chi square test and Fisher's exact test were used. $p<0.05$ was considered to indicate a statistically significant difference and false discovery rate (FDR) $p$-values were calculated. Analyses were performed using GraphPad Prism 4.0 (GraphPad Software, Inc., San Diego, CA, USA), StatsDirect Statistical Software Version 2.4.4 (StatsDirect Ltd., Altrincham, UK), and MedCalc (Version 7.4 for Windows; MedCalc, Ostend, Belgium). HAPSTAT software was used to estimate the frequencies of allele combinations of the PAI-1 polymorphisms. Current versions of the HAPSTAT software (v.3.0) are available from www.bios.unc.edu/ lin/hapstat/.

Supplementary Materials: Supplementary materials can be found at http://www.mdpi.com/2075-4426/10/4/257/s1, Table S1: Synergic effect of PAI-1 polymorphisms with clinical risk factor, Table S2: Information of PAI-1 polymorphism for PCR-RFLP analysis.

Author Contributions: Data curation, J.-H.S. and I.J.K.; Funding acquisition, N.K.K.; Investigation, H.S.P., J.-H.S., C.S.R., J.Y.L. and E.J.K.; Project administration, I.J.K. and N.K.K.; Resources, J.-H.S. and I.J.K.; Supervision, I.J.K. and N.K.K.; Writing—original draft, H.S.P.; Writing—review and editing, H.S.P. and N.K.K. All authors have read and agreed to the published version of the manuscript.

Funding: This work was supported by the National Research Foundation of Korea (NRF) grant funded by the Korean government (MSIT) (2018R1D1A1A09082764).

Conflicts of Interest: The authors declare no conflict of interest.

\section{References}

1. Naghavi, M.; Wang, H.; Lozano, R.; Davis, A.; Liang, X.; Zhou, M. GBD 2013 Mortality and Causes of Death Collaborators. Global, regional, and national age-sex specific all-cause and cause-specific mortality for 240 causes of death, 1990-2013: A systematic analysis for the Global Burden of Disease Study 2013. Lancet 2015, 385, 117-171.

2. Breslow, J.L. Cardiovascular disease burden increases, NIH funding decreases. Nat. Med. 1997, 3, 600-601. [CrossRef] [PubMed]

3. Park, H.S.; Kim, I.J.; Kim, E.G.; Ryu, C.S.; Lee, J.Y.; Ko, E.J.; Park, H.W.; Sung, J.H.; Kim, N.K. A study of associations between CUBN, HNF1A, and LIPC gene polymorphisms and coronary artery disease. Sci. Rep. 2020, 10, 16294. [CrossRef] [PubMed]

4. Rubinstein, A. National Cholesterol Education Program, second report of the Expert Panel on detection, evaluation, and treatment of high blood cholesterol in adults. Circulation 1995, 91, 908-909. [PubMed]

5. Won, H.H.; Natarajan, P.; Dobbyn, A.; Jordan, D.M.; Roussos, P.; Lage, K.; Raychaudhuri, S.; Stahl, E.; Do, R. Disproportionate Contributions of Select Genomic Compartments and Cell Types to Genetic Risk for Coronary Artery Disease. PLoS Genet. 2015, 11, e1005622. [CrossRef] [PubMed]

6. Kim, I.J.; Kim, S.H.; Cha, D.H.; Lim, S.W.; Moon, J.Y.; Kim, J.O.; Ryu, C.S.; Park, H.S.; Sung, J.H.; Kim, N.K. Association of $\mathrm{COX}_{2}-765 \mathrm{G}>\mathrm{C}$ promoter polymorphism and coronary artery disease in Korean population. Genes Genom. 2019, 41, 1055-1062. [CrossRef] [PubMed]

7. Bouzidi, N.; Hassine, M.; Fodha, H.; Ben Messaoud, M.; Maatouk, F.; Gamra, H.; Ferchichi, S. Association of the methylene-tetrahydrofolate reductase gene rs1801133 C677T variant with serum homocysteine levels, and the severity of coronary artery disease. Sci. Rep. 2020, 10, 10064. [CrossRef]

8. Jung, R.G.; Motazedian, P.; Ramirez, F.D.; Simard, T.; Di Santo, P.; Visintini, S.; Faraz, M.A.; Labinaz, A.; Jung, Y.; Hibbert, B. Association between plasminogen activator inhibitor-1 and cardiovascular events: A systematic review and meta-analysis. Thromb. J. 2018, 16, 12. [CrossRef]

9. Clowes, A.W.; Clowes, M.M.; Au, Y.P.; Reidy, M.A.; Belin, D. Smooth muscle cells express urokinase during mitogenesis and tissue-type plasminogen activator during migration in injured rat carotid artery. Circ. Res. 1990, 67, 61-67. [CrossRef]

10. Libby, P. Molecular bases of the acute coronary syndromes. Circulation 1995, 91, 2844-2850. [CrossRef] 
11. He, C.S.; Wilhelm, S.M.; Pentland, A.P.; Marmer, B.L.; Grant, G.A.; Eisen, A.Z.; Goldberg, G.I. Tissue cooperation in a proteolytic cascade activating human interstitial collagenase. Proc. Natl. Acad. Sci. USA 1989, 86, 2632-2636. [CrossRef] [PubMed]

12. Zhang, H.; Dong, P.; Yang, X.; Liu, Z. Plasminogen activator inhibitor-1 4G/5G polymorphism is associated with coronary artery disease risk: A meta-analysis. Int. J. Clin. Exp. Med. 2014, 7, 3777-3788. [PubMed]

13. Cortellaro, M.; Cofrancesco, E.; Boschetti, C.; Mussoni, L.; Donati, M.B.; Cardillo, M.; Catalano, M.; Gabrielli, L.; Lombardi, B.; Specchia, G.; et al. Increased fibrin turnover and high PAI-1 activity as predictors of ischemic events in atherosclerotic patients. A case-control study. The PLAT Group. Arter. Thromb. 1993, 13, 1412-1417. [CrossRef] [PubMed]

14. Morange, P.E.; Saut, N.; Alessi, M.C.; Yudkin, J.S.; Margaglione, M.; Di Minno, G.; Hamsten, A.; Humphries, S.E.; Tregouet, D.A.; Juhan-Vague, I. Association of plasminogen activator inhibitor (PAI)-1 (SERPINE1) SNPs with myocardial infarction, plasma PAI-1, and metabolic parameters: The HIFMECH study. Arter. Thromb. Vasc. Biol. 2007, 27, 2250-2257. [CrossRef]

15. Fan, Q.; Li, H.; Qin, Y.; Li, L.; Chen, L.; Zhang, L.; Lv, Y.; Liang, D.; Liang, Y.; Long, T.; et al. Association of SERPINE1 rs6092 with type 2 diabetes and related metabolic traits in a Chinese population. Gene 2018, 661, 176-181. [CrossRef]

16. Li, Y.; Liu, F.X.; Yuan, C.; Meng, L. Association between plasminogen activator inhibitor gene polymorphisms and osteonecrosis of the femoral head susceptibility: A case-control study. Medicine 2017, 96, e7047. [CrossRef]

17. Kim, J.O.; Han, S.H.; Lee, Y.H.; Ahn, T.K.; Lim, J.J.; Chung, Y.S.; Shin, D.E.; Lee, W.S.; Han, I.B.; Kim, N.K. Association of Plasminogen Activator Inhibitor-1 (PAI-1) Gene Polymorphisms with Osteoporotic Vertebral Compression Fractures (OVCFs) in Postmenopausal Women. Int. J. Mol. Sci. 2016, 17, 2062. [CrossRef]

18. Garcia-Gonzalez, I.J.; Valle, Y.; Sandoval-Pinto, E.; Valdes-Alvarado, E.; Valdez-Haro, A.; Munoz-Valle, J.F.; Flores-Salinas, H.E.; Figuera-Villanueva, L.E.; Davalos-Rodriguez, N.O.; Padilla-Gutierrez, J.R. The -844 G > A PAI-1 polymorphism is associated with acute coronary syndrome in Mexican population. Dis. Markers 2015, 2015, 460974. [CrossRef]

19. Su, S.; Chen, S.; Zhao, J.; Huang, J.; Wang, X.; Chen, R.; Gu, D. Plasminogen activator inhibitor-1 gene: Selection of tagging single nucleotide polymorphisms and association with coronary heart disease. Arter. Thromb. Vasc. Biol. 2006, 26, 948-954. [CrossRef]

20. Zhang, Q.; Jin, Y.; Li, X.; Peng, X.; Peng, N.; Song, J.; Xu, M. Plasminogen activator inhibitor-1 (PAI-1) 4G/5G promoter polymorphisms and risk of venous thromboembolism-A meta-analysis and systematic review. Vasa 2020, 49, 141-146. [CrossRef]

21. Akhter, M.S.; Biswas, A.; Abdullah, S.M.; Behari, M.; Saxena, R. The Role of PAI-1 4G/5G Promoter Polymorphism and Its Levels in the Development of Ischemic Stroke in Young Indian Population. Clin. Appl. Thromb. Hemost. 2017, 23, 1071-1076. [CrossRef]

22. Kuliha, M.; Roubec, M.; Goldirova, A.; Hurtikova, E.; Jonszta, T.; Prochazka, V.; Gumulec, J.; Herzig, R.; Skoloudik, D. Laboratory-Based Markers as Predictors of Brain Infarction During Carotid Stenting: A Prospective Study. J. Atheroscler. Thromb. 2016, 23, 839-847. [CrossRef] [PubMed]

23. Reis, K.A.; Onal, B.; Gonen, S.; Arinsoy, T.; Erten, Y.; Ilgit, E.; Soylemezoglu, O.; Derici, U.; Guz, G.; Bali, M.; et al. Angiotensinogen and plasminogen activator inhibitor-1 gene polymorphism in relation to renovascular disease. Cardiovasc. Interv. Radiol. 2006, 29, 59-63. [CrossRef]

24. Liang, Z.; Jiang, W.; Ouyang, M.; Yang, K. PAI-1 4G/5G polymorphism and coronary artery disease risk: A meta-analysis. Int. J. Clin. Exp. Med. 2015, 8, 2097-2107.

25. Ozolina, A.; Strike, E.; Nikitina-Zake, L.; Jaunalksne, I.; Krumina, A.; Lacis, R.; Bjertnaes, L.J.; Vanags, I. Polymorphisms on PAI-1 and ACE genes in association with fibrinolytic bleeding after on-pump cardiac surgery. BMC Anesthesiol. 2015, 15, 122. [CrossRef] [PubMed]

26. Wang, Y.; Long, J.; Wang, X.; Sun, Y. Association of the plasminogen activator inhibitor-1 (PAI-1) Gene $-6754 \mathrm{G} / 5 \mathrm{G}$ and $-844 \mathrm{~A} / \mathrm{G}$ promoter polymorphism with risk of keloid in a Chinese Han population. Med. Sci. Monit. 2014, 20, 2069-2073. [CrossRef]

27. Stringer, H.A.; van Swieten, P.; Heijnen, H.F.; Sixma, J.J.; Pannekoek, H. Plasminogen activator inhibitor-1 released from activated platelets plays a key role in thrombolysis resistance. Studies with thrombi generated in the Chandler loop. Arterioscler. Thromb. 1994, 14, 1452-1458. [CrossRef] [PubMed] 
28. Handt, S.; Jerome, W.; Braaten, J.; Lewis, J.; Kirkpatrick, C.; Hantgan, R. PAI-1 released from cultured human endothelial cells delays fibrinolysis and is incorporated into the developing fibrin clot. Fibrinolysis 1994, 8 , 104-112. [CrossRef]

29. Olave, N.C.; Grenett, M.H.; Cadeiras, M.; Grenett, H.E.; Higgins, P.J. Upstream stimulatory factor-2 mediates quercetin-induced suppression of PAI-1 gene expression in human endothelial cells. J. Cell Biochem. 2010, 111, 720-726. [CrossRef] [PubMed]

30. Lima, L.M.; Carvalho, M.; Fonseca Neto, C.P.; Garcia, J.C.; Sousa, M.O. PAI-1 4G/5G polymorphism and plasma levels association in patients with coronary artery disease. Arq. Bras. Cardiol. 2011, 97, 462-467. [CrossRef]

31. Xu, K.; Liu, X.; Yang, F.; Cui, D.; Shi, Y.; Shen, C.; Tang, W.; Yang, T. PAI-1 -675 4G/5G polymorphism in association with diabetes and diabetic complications susceptibility: A meta-analysis study. PLoS ONE 2013, 8, e79150. [CrossRef]

32. Xu, X.; Xie, Y.; Lin, Y.; Xu, X.; Zhu, Y.; Mao, Y.; Hu, Z.; Wu, J.; Chen, H.; Zheng, X.; et al. PAI-1 promoter 4G/5G polymorphism (rs1799768) contributes to tumor susceptibility: Evidence from meta-analysis. Exp. Ther. Med. 2012, 4, 1127-1133. [CrossRef]

33. Li, Y.Y. Plasminogen activator inhibitor- $14 \mathrm{~g} / 5 \mathrm{~g}$ gene polymorphism and coronary artery disease in the chinese han population: A meta-analysis. PLoS ONE 2012, 7, e33511. [CrossRef]

34. Fiuza, M. Metabolic syndrome and coronary artery disease. Rev. Port. Cardiol. 2012, 31, 779-782. [CrossRef]

35. Neeb, Z.P.; Edwards, J.M.; Alloosh, M.; Long, X.; Mokelke, E.A.; Sturek, M. Metabolic syndrome and coronary artery disease in Ossabaw compared with Yucatan swine. Comp. Med. 2010, 60, 300-315.

36. Zidi, W.; Allal-Elasmi, M.; Zayani, Y.; Zaroui, A.; Guizani, I.; Feki, M.; Mourali, M.S.; Mechmeche, R.; Kaabachi, N. Metabolic Syndrome, Independent Predictor for Coronary Artery Disease. Clin. Lab. 2015, 61, 1545-1552. [CrossRef]

37. Won, K.B.; Chang, H.J.; Sung, J.; Shin, S.; Cho, I.J.; Shim, C.Y.; Hong, G.R.; Kim, Y.J.; Choi, B.W.; Chung, N. Differential association between metabolic syndrome and coronary artery disease evaluated with cardiac computed tomography according to the presence of diabetes in a symptomatic Korean population. BMC Cardiovasc. Disord. 2014, 14, 105. [CrossRef]

38. National Cholesterol Education Program Expert Panel on Detection, Evaluation, and Treatment of High Blood Cholesterol in Adults (Adult Treatment Panel III). Third Report of the National Cholesterol Education Program (NCEP) Expert Panel on Detection, Evaluation, and Treatment of High Blood Cholesterol in Adults (Adult Treatment Panel III) final report. Circulation 2002, 106, 3143-3421. [CrossRef]

39. Jeon, Y.J.; Kim, Y.R.; Lee, B.E.; Choi, Y.S.; Kim, J.H.; Shin, J.E.; Rah, H.; Cha, S.H.; Lee, W.S.; Kim, N.K. Genetic association of five plasminogen activator inhibitor-1 (PAI-1) polymorphisms and idiopathic recurrent pregnancy loss in Korean women. Thromb. Haemost. 2013, 110, 742-750. [CrossRef]

Publisher's Note: MDPI stays neutral with regard to jurisdictional claims in published maps and institutional affiliations.

(C) 2020 by the authors. Licensee MDPI, Basel, Switzerland. This article is an open access article distributed under the terms and conditions of the Creative Commons Attribution (CC BY) license (http://creativecommons.org/licenses/by/4.0/). 